\title{
Expression of B Locus Beta 2 (BLB2) Gene at Cytolytic and Latent Immune Response Stages of Immunocompetence in Nigerian Indigenous Chickens
}

\author{
Abdulraheem Adedeji Bello-Ibiyemi ${ }^{1}$, Adeyemi Sunday Adenaike1, Micheal Irewole Takeet ${ }^{2}$, \\ Akpan Ubong1, Christian Obiora Ndubuisi Ikeobi ${ }^{1}$ \\ ${ }^{1}$ Department of Animal Breeding and Genetics, College of Animal Science and Livestock Production, Federal University of \\ Agriculture Abeokuta, Ogun State, Nigeria. \\ ${ }^{2}$ Department of Veterinary Microbiology and Parasitology, College of Veterinary Medicine, Federal University of Agriculture \\ Abeokuta, Ogun State, Nigeria \\ Email: ^ballomi13@gmail.com
}

How to cite this paper: Bello-Ibiyemi, A.A., Adenaike, A.S., Takeet, M.I., Ubong, A. and Ikeobi, C.O.N. (2021) Expression of B Locus Beta 2 ( $B L B 2$ ) Gene at Cytolytic and Latent Immune Response Stages of Immunocompetence in Nigerian Indigenous Chickens. Open Journal of Animal Sciences, 11, 164-174.

https://doi.org/10.4236/ojas.2021.112013

Received: February 1, 2021

Accepted: April 5, 2021

Published: April 8, 2021

Copyright (c) 2021 by author(s) and Scientific Research Publishing Inc. This work is licensed under the Creative Commons Attribution International License (CC BY 4.0).

http://creativecommons.org/licenses/by/4.0/

\begin{abstract}
An economically-important trait in poultry for which gene identification continues to be a challenge is immune response. The objective of the study was to quantitate the expression of major histocompatibility complex (MHC) class II $B L B 2$ gene at cytolytic and latent immune response stages in Nigerian indigenous chickens. A total of 108 Nigerian indigenous chickens (NIC) were sourced across the South-western states in Nigeria. The birds were inoculated with sheep red blood cells (SRBC), after which blood samples were obtained (5 days post-inoculation) and antibody haemagglutination test was carried out to place the birds into groups of high and low antibody titre levels. The categorisation of the birds resulted in six groups of normal feather high, normal feather low, naked neck high, naked neck low, frizzle feather high and frizzle feather low antibody groups. A total of 48 chicks were selected from the progeny for gene expression studies. Surgical excision of thymus and spleen was carried out for the detection of cytolytic and latent responses of the birds. $\beta$-actin was used as the endogenous control and the critical threshold method $\left(2^{-\Delta \Delta C \mathrm{r}}\right)$ was carried out for the determination of fold change. The fold change of spleen tissue expression at cytolytic immune response of the birds was 30,362.44 compared to latent response 294.07; and the fold change of thymus expression at cytolytic immune response of the birds was 51.98 compared to latent response 5.24. At both cytolytic and latent stages of immune response to SRBC antigen, $B L B 2$ expression in the spleen was com-
\end{abstract}


paratively higher than in the thymus and the height of transcriptional activity was associated with the cytolytic stage. The birds of high titre at both the cytolytic and the latent responses had higher mRNA expression. This study concluded that $B L B 2$ gene expression in the Nigerian indigenous chicken was induced at the cytolytic stage and repressed at the latent stage. During avian infections, the category of high immune response birds would perform better than the low immune response counterpart; and the protective response that $B L B 2$ gene offers will be repressed from one time point to the other.

\section{Keywords}

Nigerian Indigenous Chickens, BLB2 Gene Expression, Sheep Red Blood Cells

\section{Introduction}

Chickens represent the most numerous poultry species [1] and widely distributed in Nigeria [2]. Local chickens of the tropics are mainly kept for meat and egg production and sold sometimes for their socio-economic value [3]. One of the hot spots in chicken genetics and breeding research has been to identify major histocompatibility complex (MHC) haplotypes. Chen et al. [4] reported that $\mathrm{MHC}$ is a constellation of immune and immune-related genes involved in infectious disease prevention. It plays a fundamental role in both humoral and cellular immunity [5]. Thus, it is the most polymorphic loci in the chicken genome [6], containing two genetically-unlinked clusters; the B complex (MHC-B) and the restriction fragment pattern-Y (Rfp-Y) region [7]. The MHC-B contains the class I (BF), class II $\beta$ (BLB), and extended class IV (BG) regions [8].

As reviewed by Han et al. [9], many approaches have been used to assess chicken MHC genotypes, including 2-dimensional electrophoresis, DNA random fragment length polymorphism (RFLP), single-strand conformation polymorphism, a genotyping method based on DNA sequence typing and red blood serological procedures. Serological procedure involving the use of sheep red blood cells (SRBC) have been used and reported in establishing some birds as chicken lines but such procedures have not been utilized in the Nigerian indigenous chicken. Ngongeh et al. [10] reported that there was evidence that resistance or susceptibility to some avian diseases was associated with inheritance and eventually, chicken lines resistant to such diseases could be established by genetic selection. No such documented evidence is known to the authors about the Nigerian indigenous (local) chicken in comparison to their exotic counterparts such as, broilers and layers where some related studies had already been conducted. Sheep red blood cell (SRBC) is an antigen that has been used to monitor immune response in chickens and has been used frequently as a potential antigen in immune response for it is non-pathogenic, strongly immunogenic and does not interfere with the measurement of antibody response [3]. 
The ability to simultaneously measure the transcript abundance of every known gene in a tissue sample opens the possibility of using gene expression as an intermediary molecular procedure to highlight genes governing a trait. Mapping of the encoding chicken genes suggests that BLB, the gene for MHC class II $\beta$ chain, is a positional candidate gene [11]. BLB2 gene, pertaining to immune defense is regarded a major gene and expressed in a large variety of tissues in relatively high quantity in chickens [12]. Thus, the MHC is considered a barometer for the genetic health of species populations [13].

Data on the MHC class II and specifically BLB2 gene (classified as a major gene in immune defence) expression and characterisation in Nigerian indigenous chickens (NIC) therefore requires identification and proper elucidation of the immunological variation in the major genotypes (naked neck, frizzle and normal feathered chickens) based on quantitation indices. Thus, the alarming rate of loss of birds due to immune compromise at the point of disease attack which represents a substantial burden to farmers has evoked the need to study the precise mechanism of the immune protective mechanism via the $B L B 2$ gene at the cytolytic and the latent stages in Nigerian indigenous chickens. Cytolytic response establishes after initial infection of birds followed immediately by a response phase that extends from 3 to 6 days post-infection [14]. Following cytolytic response, there is a switch to latent phase in $\mathrm{T}$ cells which occurs approximately 7 days post-infection [15].

\section{Methods}

\subsection{Experimental Site}

The study was carried out at the Poultry Unit of the Directorate of University Farms (DUFARMS), Animal Breeding and Genetics Departmental laboratory, the Biotechnology Centre Laboratory of the Federal University of Agriculture, Abeokuta and International Institute of Tropical Agriculture (IITA) Oyo State, Nigeria.

\subsection{Experimental Animals}

A total of 108 indigenous chickens were sourced across the six South-western states in Nigeria including Lagos, Ogun, Oyo, Osun, Ekiti and Ondo States, with 18 birds obtained per State, six (6) of each genotype of frizzle feather, naked neck and normal feather indigenous chickens and two (2) males and four (4) females. The birds were acclimatized and screened for diseases two weeks after sourcing. They were inoculated with sheep red blood cells (SRBC), after which blood samples were obtained from them (5 days post-inoculation) and antibody hemagglutination test was carried out to place the birds into groups of high and low antibody titres. One millilitre $(1 \mathrm{ml})$ of washed $1 \%$ suspension SRBC antigen was intravenously administered to each of the birds. After 5 days post-injection, $1.5 \mathrm{ml}$ of blood sample was collected from each bird via the jugular vein and was emptied into a non-heparinized bottle to induce clotting. Serum samples were 
separated from clotted blood and stored in eppendorf tube for hemagglutination test. Based on the result of the hemagglutination assay, birds from each genotype were grouped into high titre $(\geq 9)$ and low titre $(\leq 7)$ categories [16]. The categorisation of the birds into high and low titres resulted in six groups of two categories; high and low antibody titres. Hence, there were normal feather high, normal feather low, naked neck high, naked neck low, frizzle feather high and frizzle feather low antibody groups. Thereafter, artificial insemination was done to obtain progeny chicks. Semen from high titre males was used to inseminate high titre females and semen from low titre males was used to inseminate low titre females. Eggs generated from the birds were separated into different trays at the hatchery to avoid mixing up of birds after hatching.

\subsection{Sample Collection}

The chicks obtained across each group were sacrificed via cervical subluxation and dissected, commencing from eight weeks of age. Tissues (thymus and spleen) were subsequently removed aseptically, cleaned off, weighed (recorded) and placed in eppendorf tubes. Using blunt forceps, the tissues were teased apart immediately and stored in RNA latter to prevent degradation of the RNA prior to the time of extraction. This was thereafter stored in a $-20^{\circ} \mathrm{C}$ freezer, until the determination of the level of expression of the desired genes was carried out.

A total of 48 birds were isolated for surgical excision of thymus and spleen for detection of cytolytic and latent responses of the birds at eight (8) weeks. Cytolytic response detection in high and low titre chicks followed a selection of four birds (males and females) which were sacrificed for sample collection across the normal feather, naked neck and frizzle feather groups resulting in 24 birds. Latent response was detected in high and low titre birds by selecting two birds (male and female) which were sacrificed for sample collection across the normal feather low, naked neck low and frizzle feather low groups making a total of 24 birds. For cytolytic response, samples were obtained 5 days post-inoculation while for latent response, samples were obtained 14 days post-inoculation.

\subsection{RNA Extraction and Quantitation Analysis}

The total RNA of each tissue sample (thymus and spleen) was extracted using Isolate II RNA mini-kits (Bioline, London, UK) according to the manufacturer's protocol. The primers used in the amplification of the $B L B 2$ and $\beta$-actin genes were BLB2F (5'-CCCTCGGCGTTCTTCTTCTAC-3') and BLB2R (5'-CCCTCGG CGTTCTTCTTCTAC-3') and $\beta$-actinF (5'-GAGAAATTGTGCGTGACATCA-3') and $\beta$-actinR (5'-CCTGAACCTCTCATTGCCA-3') as reported by Lian et al. [17].

Two-step qPCR was conducted with the cDNA synthesis. Quantitation of reverse transcription product (cDNA) was achieved using SensiFAST ${ }^{\mathrm{TM}}$ SYBR Hi-ROX kit (Bioline, London, UK), using real time ABI 7500 machine which adopted two-step cycling; 1 cycle at $95^{\circ} \mathrm{C}$ for 2 minutes (polymerase reaction) and 40 cycles at $95^{\circ} \mathrm{C}$ 
for 5 seconds (denaturation) and $65^{\circ} \mathrm{C}$ for 30 seconds (annealing/extension). The total reaction volume mixture used was $10 \mu \mathrm{l}$ which included $2 \mathrm{x}$ SensiFAST SYBR Hi-ROX mix $5 \mu \mathrm{l}, 0.5 \mu \mathrm{M}$ forward primer, $0.5 \mu \mathrm{l}$ reverse primer, $2.5 \mu \mathrm{l}$ template $\mathrm{cDNA}$ and $1.5 \mu \mathrm{l}$ water.

\subsection{Statistical Analysis}

The cycle threshold (Ct) from the qRT-PCR reactions of accumulated fluorescent signal curves was used to compute mean expression levels of the gene in tissues at different response phases and analysis of variance was conducted. Significant means were separated using least significant difference mean comparisons in R [18]. Interactions were not significant and thus unreported. The statistical model employed was:

$$
Y_{i j k l}=\mu+\alpha_{i}+\beta_{j}+G_{k}+H_{l}+e_{i j k l}
$$

where

$Y_{i j k l}=$ is the response/dependent variable

$\mu=$ is the overall mean response

$\alpha_{i}=$ is the effect due to the $i^{\text {th }}$ genotype ( $i=$ normal feather, naked neck, frizzle)

$\beta_{j}=$ is the effect due to the $j^{\text {th }}$ antibody $(j=$ high, low $)$

$G_{k}=$ is the effect due to the $k^{\text {th }} \operatorname{sex}(k=$ male, female)

$H_{l}=$ is the effect due to the $I^{\text {th }}$ tissue ( $I=$ thymus, spleens)

$e_{i j k l}=$ residual error

\section{Results}

The confirmation of presence of RNA after extraction from the tissue samples informed the choice of data analysis. Effects of tissue, genotype, antibody titre level and sex on the mean threshold cycle $\left(\mathrm{C}_{\mathrm{T}}\right)$ values of $B L B 2$ gene expression of Nigerian indigenous chicken at cytolytic immune response stage are presented in Table 1. The results show that tissue $(p<0.001)$, titre grouping $(p<0.001)$ and sex $(p<0.01)$ significantly affected the mean expression of $B L B 2$ gene at $c y-$ tolytic immune response phase.

Table 1. Analysis of variance showing effects of tissue, genotype, titre and sex on BLB2 gene expression at the cytolytic stage of Nigerian indigenous chickens based on $\mathrm{C}_{\mathrm{T}}$.

\begin{tabular}{ccc}
\hline Source & d.f & Mean square \\
\hline Tissue & 1 & $774.94^{* * *}$ \\
Genotype & 2 & 98.29 \\
Titre & 1 & $965.11^{* * *}$ \\
Sex & 1 & $252.04^{* *}$ \\
\hline
\end{tabular}

${ }^{* *} p<0.01,{ }^{* * *} p<0.001$. 
Table 2 shows separated $\Delta \mathrm{C}_{\mathrm{T}}$ threshold means and fold difference $\left(2^{-\Delta \Delta \mathrm{Cr}}\right)$ according to tissue, titre and sex at the cytolytic stage of Nigerian indigenous chickens. The result shows also that tissue $(p<0.001)$, titre grouping $(p<0.001)$ and sex $(p<0.01)$ significantly impacted the overall expression of $B L B 2$ gene at cytolytic immune response phase.

The effects of tissue, genotype, titre and sex on the mean $\mathrm{C}_{\mathrm{T}}$ of $B L B 2$ gene expression of Nigerian indigenous chickens at latent stage are presented in Table 3. The results show that tissue $(p<0.001)$, titre grouping $(p<0.01)$ and $\operatorname{sex}(p<$ $0.05)$ significantly affected the latent immune response phase.

Consequently, effects of tissue, genotype, titre and sex on $\triangle \mathrm{CT}$ threshold means and the fold difference $\left(2^{-\triangle \Delta \mathrm{Cr}}\right)$ of $B L B 2$ gene expression of Nigerian indigenous chickens at latent stage is presented in Table 4 . The result shows that tissue $(p<0.001)$, titre grouping $(p<0.01)$ and sex $(p<0.05)$ affected the latent immune response phase.

Table 2. Effects of tissue, titre, sex and genotype at the cytolytic gene expression in Nigerian indigenous chickens.

\begin{tabular}{cccc}
\hline Source & Category & $\Delta \mathrm{CT} \pm \mathrm{SD}$ & $2^{-\Delta \Delta \mathrm{CT}^{\mathrm{T}}}$ \\
\hline Tissue & Spleen & $14.89 \pm 2.03^{\mathrm{a} * * *}$ & $30,362.44$ \\
& Thymus & $5.70 \pm 1.21^{\mathrm{b} * * *}$ & 51.98 \\
\hline Titre & High & $12.57 \pm 0.49^{*}$ & 6080.61 \\
& Low & $7.36 \pm 0.32^{\mathrm{b} *}$ & 164.28 \\
\hline Sex & Male & $13.75 \pm 0.44^{\mathrm{a} * *}$ & $13,777.25$ \\
& Female & $6.08 \pm 0.41^{\mathrm{b} *}$ & 67.65 \\
\hline Genotype & Naked neck & $8.03 \pm 1.21$ & 261.38 \\
& Frizzle feather & $7.27 \pm 0.91$ & 154.34 \\
& Normal feather & $7.71 \pm 1.03$ & 209.38 \\
\hline
\end{tabular}

${ }^{a b c}$ Means in the same column within variable grouping bearing different subscripts are significantly different; $\mathrm{SD}-$ Standard Deviation; $\mathrm{C}_{\mathrm{T}}-$ Cycle threshold; $\Delta \mathrm{CT}-$ Delta cycle threshold.

Table 3. Effects of tissue, genotype, titre and sex of latent gene expression of Nigerian indigenous chicken based on the $\mathrm{C}_{\mathrm{T}}$ threshold values.

\begin{tabular}{ccc}
\hline Source & D.F & Mean square \\
\hline Tissue & 1 & $479.14^{* * *}$ \\
Genotype & 2 & 54.14 \\
Titre & 1 & $212.84^{* * *}$ \\
Sex & 1 & $145.25^{* *}$ \\
\hline
\end{tabular}

${ }^{* *} p<0.01,{ }^{* * *} p<0.001 ;$ D.F-degree of freedom. 
Table 4. Effects of tissue, titre, sex and genotype at the latent gene expression in Nigerian indigenous chickens.

\begin{tabular}{cccc}
\hline Source & Type & $\Delta \mathrm{CT}^{2} \pm \mathrm{SD}$ & $2^{-\Delta \Delta \mathrm{Cr}}$ \\
\hline Tissue & Spleen & $8.20 \pm 1.03^{\mathrm{a} *}$ & 294.07 \\
& Thymus & $2.39 \pm 0.32^{\mathrm{b} *}$ & 5.24 \\
\hline Titre & High & $8.14 \pm 0.32^{\mathrm{a} *}$ & 282.09 \\
& Low & $1.83 \pm 0.14^{\mathrm{b} *}$ & 3.56 \\
\hline Sex & Male & $7.13 \pm 0.35$ & 140.70 \\
& Female & $6.90 \pm 0.44$ & 119.43 \\
\hline Genotype & Naked neck & $6.48 \pm 0.45$ & 89.26 \\
& Frizzle feather & $5.92 \pm 0.66$ & 60.55 \\
& Normal feather & $6.02 \pm 0.62$ & 64.89 \\
\hline
\end{tabular}

${ }^{\mathrm{abc}}$ Means in the same column within variable grouping bearing different subscripts are significantly different; ${ }^{* *} p<0.01,{ }^{* *} p<0.001 ; \mathrm{SD}-$ Standard Deviation; $\Delta \mathrm{C}_{\mathrm{T}}-$ Delta cycle threshold.

\section{Discussion}

Tissue difference in $\mathrm{C}_{\mathrm{T}}$ values of spleen and thymus in the Nigerian indigenous chickens at cytolytic and latent immune response phases show that, average mean estimate for spleen and thymus at cytolytic phase was elevated. This result agrees with Patterson et al. [19] that $\mathrm{C}_{\mathrm{T}} \mathrm{s}$ less than 29 are strong positive reactions indicative of abundant target nucleic acid in the sample. Birds categorised as having high titre estimates of immune response at the cytolytic stage had higher $\mathrm{C}_{\mathrm{T}}$ than at the latent phase, and this distinction was similar to the low immune response category. This finding conforms to the report by Le Blastier et al. [20] that $\mathrm{C}_{\mathrm{T}} \mathrm{s}$ of $30-38$ are moderate while $\mathrm{C}_{\mathrm{T}} \mathrm{s}$ of $38-40$ are weak reactions indicating minimal amounts of target nucleic acids. The result from this study suggests that higher mRNA content after extraction is an indication of marked deviation resulting from the low and high groups. Sarson et al. [21] reported that the $\mathrm{C}_{\mathrm{T}}$ of genes in the MHC-II pathway showed lower expression of genes of infected compared to uninfected chickens.

Observations from this study indicate that the $\mathrm{C}_{\mathrm{T}}$ values at the cytolytic phase were affected by tissue. Tissue expression of $B L B 2$ gene considering $2^{-\triangle \triangle C T}$ represents the fold difference between the sample and the calibrator. The $2^{-\Delta \Delta \mathrm{Cr}_{\mathrm{r}}}$ shows that the fold change of spleen at the cytolytic immune response of the birds was more profound $(30,362.44)$ compared to the latent response (294.07). This could be due to the modulation of physiological manifestation of antigen response, which results in a burst of productive/restrictive infection in B cells that it is associated with high transcriptional activity of antigen at the cytolytic immune response stage which is followed by attraction and subsequent infection of thymus-derived $\mathrm{CD}^{+} \mathrm{T}$ cells at about 7 days post-infection. This finding is 
similar to the report of Heidari et al. [22] which verified an increase in physiological response in chicken following exposure to antigen in less than one week. Thymic expression was higher at the cytolytic phase compared to the latent phase of the high immune response birds than the low category. This result is congruent with the reports of Lian et al. [17] that the expression of genes in the MHC-IIpathway showed a decreased trend at all-time points in spleens of infected chickens compared to uninfected controls.

According to titre separation, $2^{-\Delta \Delta \mathrm{Cr}}$ values showed higher expression in birds categorised as high than in low counterparts at both the cytolytic and latent expression; and the fold difference on the overall. This observation is supported by the report of Xiaofei and Shannon [23] that experimental chicken lines would have a high possibility of multiple gene copy number per cell. Furthermore, the observation is in concord with the findings of Thanthrige-Don et al. [24] that there is significant down-regulation of MHC-II $\beta$-chain expression at 4,14 , and 21 days post-infection ( $\mathrm{d}$ p.i.), and other components of the MHC-II heterotrimer ( $\alpha$ chain and Ii chain) are also down-regulated at 4- and 21-days post-inoculation. Considering our results with the high and low categories at cytolytic immune response; and the same categories at the latent immune response, it could be inferred that the response of chicks of high-titre birds would most probably confer better survivability than the low-titre counterpart. Consequently, it would not be concluded that there was down-regulation considering the major gene BLB2 but repression. Heidari et al. [22] proposed that log fold change less than zero depicted down regulation and when the log fold values are greater than zero, it is not concluded as down-regulation.

Mean differences in the birds was also observed as the males had higher expression $\left(2^{-\Delta \Delta \mathrm{Cr}}\right)$ estimates than females at both immuncompetence response stages. This observation conforms with the report of Zhao et al. [25] that nearly every cell in the body of chickens (from wattle to toe) has an inherent sex identity which is expressed; and in contrast with mammals, it demonstrates that avian somatic cells possess an inherent sex identity and as such, in birds, sexual differentiation is substantively cell-autonomous. In addition, it has been reported by Pierre [26] that both primary and secondary immune organs can be dramatically influenced by sex hormones.

\section{Conclusion}

At both cytolytic and latent stages of immune response to SRBC antigen, BLB2 expression in spleen was comparatively higher than thymus and the height of transcriptional activity was associated with the cytolytic stage. Consequently, according to antibody categorisation (high and low), birds of high titre at both cytolytic and latent responses had the highest mRNA expression. Nigerian indigenous birds of the male sex apparently had increased expression at cytolytic response stage at 8 weeks of age. During avian infections, it is proposed that the category of high immune response birds would most probably perform better 
than the low immune response counterpart. The use of SRBC to understand this phenomenon and the protective response $B L B 2$ gene provides offer an understanding that the gene will be repressed from one time point to the other. It is important to note that mRNA levels documented in this report may not correlate with the amount of active protein expressed in vivo in the birds if there was post-translational modification of $B L B 2$ product in the Nigerian indigenous chicken lines. It is therefore recommended that when considering diseases/infections responsible for substantial economic losses that plague the poultry industry, high response birds should be preferred. Also, for the purpose of commercial production, Nigerian indigenous chicken of the high immune response birds should be favoured. Studies should be carried out to compare the performance on the basis of immune traits to traits of economic importance (meat/body weight and egg production) and diseases.

\section{Acknowledgements}

This research was supported by Tertiary Education Trust Fund (TETFUND) Federal University of Agriculture, Abeokuta (FUNAAB). Special thanks to the Directorate of Grants Management FUNAAB.

\section{Ethical Approval and Consent to Participate}

All protocols for this research were approved by the Animal Care and Use Committee of the Federal University of Agriculture, Abeokuta, Nigeria.

\section{Author's Contribution}

CONI, ASA and BIAA conceptualized and designed the study. BIAA collected the data and analyzed it. BIAA interpreted the results and drafted the manuscript and CONI supervised the study. MIT and ASA co-supervised and made critical revision of the manuscript. All authors have read and approved the manuscript.

\section{Conflicts of Interest}

The authors declare no conflicts of interest regarding the publication of this paper.

\section{References}

[1] Xiang, H.J., Gao, H., Yu, B., Zhou, H., Cai, D., Zhang, Y., Chen, X., Wang, X., Hofreiter, M. and Zhao, X. (2014) Early Holocene Chicken Domestication in Northern China. Proceedings of the National Academy of Sciences of the United States of America, 111, 17564-17569.

[2] Adebambo, A.O., Mobegi, V.A., Mwacharo, J.M., Oladejo, B.M., Adewale, R.A., Ilori, L.O., Makanjuola, B.O., Afolayan, O., Bjørnstad, G., Jianlin, H. and Hanotte, O. (2010) Lack of Phylogeographic Structure in Nigerian Village Chickens Revealed by Mitochondrial DNA D-Loop Sequence Analysis. International Journal of Poultry Science, 9, 503-507. https://doi.org/10.3923/ijps.2010.503.507 
[3] Osei-Amponsah, K., Boa-Amponsem, B.B.K. and Naazie, A. (2013) Characterization of Primary Immune Response in Ghanaian Local, Sasso T-44 and Broiler Chickens to Sheep Red Blood Cell Antigens. Animal Genetic Resources, 53, 51-55. https://doi.org/10.1017/S2078633613000258

[4] Chen, L-C., Lan, H., Sun, L., Deng, Y.L., Tang, K.-E. and Wan, Q.-H. (2015) Genomic Organization of the Crested Ibis MHC Provides New Insight into Ancestral Avian MHC Structure. Scientific Reports, 5, Article No. 7963. https://doi.org/10.1038/srep07963

[5] Patel, N., Conejero, L., De Reynal, M., Easton, A., Bancroft, G.J. and Titball, R.W. (2011) Development of Vaccines against Burkholderia pseudomallei. Frontiers in Microbiology, 2, Article 198. https://doi.org/10.3389/fmicb.2011.00198

[6] Eimes, J.A., Bollmer, J.L., Dunn, P.O., Whittingham, L.A. and Wimpee, C. (2010) MHC Class II Diversity and Balancing Selection in Greater Prairie-Chickens. Genetica, 138, Article No. 265. https://doi.org/10.1007/s10709-009-9417-4

[7] Kaufman, J., Jacob, J., Shaw, I., Walker, B., Milne, S., Beck, S. and Salomonsen, J. (1999) Gene Organisation Determines Evolution of Function in the Chicken MHC. Immunological Reviews, 167, 101-117. https://doi.org/10.1111/j.1600-065X.1999.tb01385.x

[8] Salomonsen, J., Marston, D., Avila, D., Bumstead, N., Johansson, B., Juul-Madsen, H., Olesen, G.D., Riegert, P., Skjødt, K., Vainio, O., Wiles, M.V. and Kaufman, J. (2003) The Properties of the Single Chicken MHC Classical Class II a Chain (B-LA) Gene Indicate an Ancient Origin for the DR/E-Like Isotype of Class II Molecules. Immunogenetics, 55, 605-614. https://doi.org/10.1007/s00251-003-0620-7

[9] Han, B., Lian, L., Qu, L., Zheng, J. and Yang, N. (2013) Abundant Polymorphisms at the Microsatellite Locus LEI0258 in Indigenous Chickens. Poultry Science, 92, 3113-3119. https://doi.org/10.3382/ps.2013-03416

[10] Ngongeh, A.N, Amaechi, O., Emeka, N. and Gurama, K.S. (2017) Comparative Response of the Nigerian and Broiler Chickens to a Field Caecal Isolate of Eimeria Oocysts. Journal of Pathogens, 2017, Article ID 2674078. https://doi.org/10.1155/2017/2674078

[11] Niikura, M., Liu, H.-C., Dodgson, J.B. and Cheng, H.H. (2004) A Comprehensive Screen for Chicken Proteins That Interact with Proteins Unique to Virulent Strains of Marek's Disease Virus. Poultry Science, 83, 1117-1123. https://doi.org/10.1093/ps/83.7.1117

[12] Jacob, J.P., Milne, S., Beck, S. and Kaufman, J. (2000) The Major and a Minor Class II Beta-Chain (B-LB) Gene Flank the Tapasin Gene in the B-F/B-L Region of the Chicken Major Histocompatibility Complex. Immunogenetics, 51, 138-147. https://doi.org/10.1007/s002510050022

[13] Shafer, A.B, Fan, C.W., Côté, S.D. and Coltman, D.W. (2012) Lack of Genetic Diversity in Immune Genes Predates Glacial Isolation in the North American Mountain Goat (Oreamnos americanus). Journal of Heredity, 103, 371-379. https://doi.org/10.1093/jhered/esr138

[14] Abdul-Careem, M.F., Hunter, B.D, Lee, L.F., Fairbrother, J.H., Haghighi, H.R. Read, L., Parvizi, P., Heidari, M. and Sharif, S. (2008) Host Responses in the Bursa of Fabricius of Chickens Infected with Virulent Marek's Disease Virus. Virology, 379, 256-265. https://doi.org/10.1016/j.virol.2008.06.027

[15] Li, X.X., Han, L.X. and Han, J.L. (2010) No Specific Primer Can Independently Amplify the Complete Exon 2 of Chicken BLB1 or BLB2 Genes. International Journal of Poultry Science, 9, 192-197. https://doi.org/10.3923/ijps.2010.192.197 
[16] Gauri, J. (2009) Candidate Gene Analysis of Interleukin Genes in Kadakanath Native Chicken. Thesis Submitted for the Degree of Doctor of Philosophy, M.J.P. Rohilkhand University, Bareilly, India, 1-155.

[17] Lian, L., Qu, L.J., Zheng, J.X., Liu, C.J., Zhang., J.P., Chen, Y.M., Xu, G.Y. and Yang, N. (2010) Expression Profiles of Genes within a Subregion of Chicken Major histocompatibility Complex B in Spleen after Marek's Disease Virus Infection. Poultry Science, 89, 2123-2129. https://doi.org/10.3382/ps.2010-00919

[18] R Core Team (2015) A Language and Environment for Statistical Computing. R Foundation for Statistical Computing, Vienna, Austria.

[19] Paterson, C., Yanhong, W., Joel, E.K. and Amanda, J.L. (2014) Schizophrenia Risk Variation in the NRG1 Gene Exerts Effects on NRG1-IV Splicing During Fetal and Early Postnatal Neocortical Development. American Journal of Journal of Psychiatry, 171, 979-989. https://doi.org/10.1176/appi.ajp.2014.13111518

[20] Le Blastier, S., Aurore, H., Matthew, C., Lionel, S., Françoise, T., Marc, D., Martine, R. and Jean-Yves, M. (2010) Phosphate Starvation Triggers Production and Secretion of an Extracellular Lipoprotein in Caulobacter crescentus. PLoS ONE, 5, e14198. https://doi.org/10.1371/journal.pone.0014198

[21] Sarson, A.J., Abdul-Careem, M.F., Zhou, H. and Sharif, S. (2006) Transcriptional Analysis of Host Responses to Marek's Disease Viral Infection. Viral Immunology, 19, 747-758. https://doi.org/10.1089/vim.2006.19.747

[22] Heidari, M., Huebner, M., Kireev, D. and Robert, F.S. (2008) Transcriptional Profiling of Marek's Disease Virus Genes During Cytolytic and Latent Infection. Virus Genes, 36, 383-392. https://doi.org/10.1007/s11262-008-0203-7

[23] Xiaofei, W. and Shannon, B. (2014) Copy Number Variation in Chickens: A Review and Future Prospects. Microarrays, 3, 24-38. https://doi.org/10.3390/microarrays3010024

[24] Thanthrige-Don, N., Read, L.R., Abdul-Careem, M.F., Mohammadi, H., Mallick, A.I. and Sharif, S. (2010) Marek's Disease Virus Influences the Expression of Genes Associated with IFN- $\gamma$-Inducible MHC Class II Expression. Viral Immunology, 23, 227-232. https://doi.org/10.1089/vim.2009.0092

[25] Zhao, D., McBride, D., Nandi, S., McQueen, H.A., McGrew, M.J., Hocking, P.M., Lewis, P.D., Sang, H.M. and Clinton, M. (2011) Somatic Sex Identity is Cell Autonomous in the Chicken. Nature, 464, 237-242. https://doi.org/10.1038/nature08852

[26] Pierre, D. (2015) Reproductive Behavior. Sturkie's Avian Physiology, 6th Edition, Elsevier, Canada, 715.

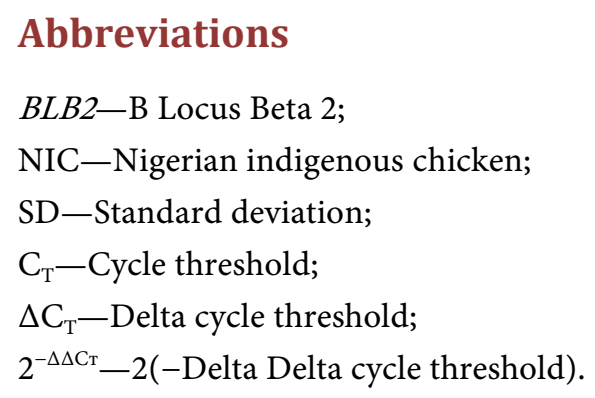

